\title{
WILLIAM MCPHERSON (1864-1951) AND WILLIAM EDWARDS HENDERSON (1870-1962): AUTHORS OF AN OUTSTANDING SERIES OF CHEMISTRY TEXTBOOKS AND MANUALS
}

\author{
Dr William P Palmer
}

\begin{abstract}
William McPherson was born near Xenia, Ohio in 1864. He attended Ohio State University obtaining B. S., M.S. and Sc.D. degrees. He obtained a Ph.D. degree from the University of Chicago and also completed about five years teaching in High Schools. He returned to Ohio State University as assistant to Professor Sidney A. Norton in 1892 where he had an illustrious career until his second retirement in 1938.
\end{abstract}

William Edwards Henderson was born in Wilkinsburg, Pennsylvania in 1870. He attended Wooster College obtaining a B. A degree in 1891. He obtained his Ph.D. degree from Johns Hopkins University in 1897. He taught at Ohio State University from 1899 to 1941.

McPherson and Henderson both saw the tremendous increase in the popularity of chemistry reflected in student numbers in the early part of the twentieth century. Observing this trend, they wrote a book, Elementary study in chemistry (1905), for High School and first year College chemistry students which included more physical chemistry than other textbooks of the period. This was followed by a chemistry laboratory manual entitled Exercises in chemistry in 1906. They published over twenty different manuals and textbooks in a variety of editions, introducing chemistry for an estimated two million students; they are thus amongst the most widely used chemistry textbooks ever published.

The McPherson and Henderson manuals are usually owned by individual students. The students perform the experiments as indicated in the manual and fill in answers in the spaces provided. Each manual is thus a unique notebook of the student's results. The "William Palmer" collection contains about 370 different of such manuals collected using Ebay over twenty years and Exercises in chemistry is the most numerous of the manual titles in the collection.

\section{WILLIAM MCPHERSON: EARLY YEARS}

William McPherson, the tenth child of William and Mary Ann (Rader) McPherson, was born on a farm four miles from Xenia, Ohio on $2^{\text {nd }}$ July 1864 (ANCESTRY). There was a small school close to the farm which provided his elementary education. He then attended Xenia High School, where he had an outstanding record despite having many tasks to complete on the farm. In Autumn 1883, he enrolled at Ohio State University (OSU) where he was successful academically and excelled in athletics (Reporter, 1951, p. 5).

When Dean McPherson came to Ohio State in 1883 from a farm near Xenia, he could outrun and out jump anyone else on campus. ... When he was a sophomore, young McPherson won the chief prize, a gold medal, known as the Franklin prize (Minderman, 1934, p. 1).

He obtained a Bachelor of Science degree in 1887, a Master's degree in 1890 and a Doctor of Science degree in 1895, all from OSU (Eblin, 1976b, p. 328). After his Bachelor's degree he started his teaching career as an instructor in physics from 1887 to 1889 at Toledo High School 
followed by a further three years teaching chemistry and Latin at Toledo Manual Training School. On $21^{\text {st }}$ June 1892, McPherson married Lucretia Heston of Toledo, Ohio (Evans, 1952); they had two children William Heston and Gertrude May (Eblin, 1976b, p. 329). Lucretia McPherson became known for her work with the Franklin County Suffrage Association and as 'a leader in all causes for civic betterment' (URL: Lucretia Heston McPherson).

Sidney Augustus Norton was appointed as Professor of Chemistry at Ohio State University in 1873 and remained as the only chemist employed by the University for the next twenty years. His initial course contained just five students. Norton taught all branches of chemistry and he also taught practical chemistry which consisted mainly of qualitative and quantitative analysis. By 1887 , student numbers had increased to 61 . The chemistry building burnt down on $12^{\text {th }}$ February 1889 (Mendenhall and Cope, 1920, p. 419). One explanation was: '... the whole structure burned down because of a lack of water to extinguish the flames.' (URL: Twelve Days of Buckeyes: “3”) A larger new building, costing $\$ 40,000$ was ready for occupancy by September 1890 (Caley, 1970, p. 130). In 1892, McPherson returned to Ohio State University (OSU) as an Assistant in Chemistry to Professor Norton. McPherson was promoted to Assistant Professor in 1893, Associate Professor in 1895 and to full Professor in 1897 after which he took over from Professor Norton as Departmental chairman. McPherson would have been a student of Norton's when he was an undergraduate. His athletic ability and popularity would have kept him as a candidate for any appropriate vacancy at OSU, so his appointment would not have been surprising. This would appear to be a smooth well-planned change, but the reality was different.

\section{CHEMISTRY AT OSU (1893-1903)}

In 1893, the Chemistry Department consisted of just McPherson and Professor Norton. Norton was 58 years old and had been solely responsible for the teaching of chemistry for twenty years at OSU. He had written a number of physics and chemistry textbooks and was interested in teaching methodology in chemistry rather than in pure research (URL: Hart). OSU had originated as a College of Agriculture and Mechanics, so it had strong Departments of Agriculture and Engineering. The students of these departments required courses in chemistry, so the Chemistry Department was very much a service department, as well having to supply the needs of its own students. The methods and timing of teaching Practical Chemistry became points of dissension between Professor Henry A. Weber of the Department of Agriculture and Professor Norton. Norton had been trained in the German laboratory tradition and 'felt strongly that the first-year course should consist of lectures and recitation, without laboratory practice' (Batchellor, 1973, p. 60). The laboratory practice had consisted firstly of examining 'reactions in the dry way with the determination of twenty-five unknowns', secondly examining reactions in the wet way and lastly examining reactions using both methods to 'determine seventy-five unknowns' (Brooks, 1930, p. 100). His view was not unreasonable for students who were going to be career chemists as he considered that it was only after the student had completed the general chemistry course and had understood basic chemistry would systematic qualitative analysis make any sense. Norton was not good at committee meetings and avoided them where possible. Opinion at the time was changing about the value of analysis being the main focus of practical chemistry Most universities and some schools now arranged a more broadly based practical chemistry for their students. Sidney Norton lost in the power struggle with Professor Weber of the Department of Agriculture. Professor Weber insisted that Agricultural students should have Practical Chemistry in their course. The chemistry department would not provide 
this so the Department of Agriculture ran its own Practical Chemistry course, which was soon followed by the removing of the engineering students from the General Chemistry Course. Student numbers for the General Chemistry Course plummeted. The University was forced to act; Norton was asked to resign as Professor and his salary was halved. McPherson was in favour of teaching Practical Chemistry and he carried out joint research with Professor Weber which resulted in two joint papers published in the Journal of the American Chemical Society (McPherson, \& Weber,1895a, pp. 312-320: 1895b, pp. 320-327). A solution to the problem was thus easily reached. McPherson wrote:

Steps were taken immediately to make laboratory work an essential part of the first-year course. As a result, the freshmen in agricultural chemistry and in engineering were transferred back to the Department of General Chemistry (McPherson, 1931, p. 644).

In 1900, Sidney Norton was given the title of Emeritus Professor of Chemistry (Mendenhall and Cope, 1920, p. 291). McPherson remained as Chair of the Chemistry Department until 1928. He obtained his Ph.D. from the University of Chicago in 1899. Mr. William Edwards Henderson, a graduate of The Johns Hopkins University joined the staff on a temporary basis in 1899 and was made permanent in 1901 (McPherson, 1931, p. 645).

\section{WILLIAM EDWARDS HENDERSON: EARLY YEARS}

William Edwards Henderson was born at Wilkinsburg, Pennsylvania on $29^{\text {th }}$ January 1870 . His father was Reverend Samuel McFarren Henderson and his mother Jane (McTeer) Henderson. His father was a minister and died when William was only nine years old. William had two elder sisters, Mary Browning Henderson and Janet Elizabeth Henderson. Jane remarried three years after her husband's death to Samuel Jabez Kirkwood (Ancestry) who was a Mathematics Professor at the College of Wooster; he would have been in a good position to assist with Henderson's home-schooling and higher education. Henderson's own description of his education can be found in his hand-written doctoral thesis, he wrote 'Owing to prolonged sickness in childhood his education, prior to entering college, was much interrupted, and was largely confined to instruction received at home' (Henderson, 1897, p. 85). Thus, little is known about the details of Henderson's elementary education, but it is possible to put together an account of his higher education. A university alumnus wrote 'Although grievously crippled as a young boy and handicapped in his locomotion, he tramped the woods and fields... (Personal communication 1). His higher education at the College of Wooster lasted seven years (Reporter, 1891, p. 1) and he received a Bachelor of Arts degree in 1891 (Eblin, 1976a, p. 209). A light-hearted account narrated the progress of the class of 1891 from their entry in the 'Junior Prep' year at the College of Wooster in 1884 to their 1891 graduation. During college, Henderson 'gave special attention to natural science' and 'stood second in a class of fifty' (Reporter, 1891, p. 1). He was an active member of Sigma Chi Beta Chapter (URL: Index $1890-1891$, p. 2) was also a member of the Athenaean Literary Society (URL: Index 18901891, p. 67)

He then taught natural science/ chemistry for two years (Reporter, 1896a, p. 4) at the College of Emporia in Kansas. It may be wondered how as a fresh graduate how he obtained a College position so quickly. The list of the nine staff at Emporia (Reporter, 1891, p. 1), includes William Kirkwood (the brother of Samuel Jabeez Kirkwood) so it is this link that was likely to have been the means of his employment. College Life (the Emporia College paper) pointed out 
that this was Henderson's first experience of teaching and that he was proving to be 'very successful as an instructor' (Reporter, 1891, p. 1). College Life in 1893 contains a staff list with photographs and opined that 'As a clear and concise instructor, Prof Henderson has but few equals' (Reporter 1893). His application for entry to J.H.U. (dated 31 ${ }^{\text {st }}$ September 1893) was 'to obtain a Doctor's degree in order to fit myself more fully for the profession of teaching' (Personal communication 2). College Life in 1894 indicated that Henderson had spent 1894 at John Hopkins University, (J.H.U.) (Reporter, 1894, p. 7). This is confirmed by the reference letters attached to his student file. These letters also explain his enthusiasm for learning pointing out that his father died leaving his mother widowed and that he was 'now borrowing money to complete his education' (Personal communication 2). His biology professor from Wooster (H. N. Mateer) was perhaps the most effusive in his praise stated that he was his best student in seven years of teaching and that:

He is a young man of very superior ability in all lines of study and is a naturalist by instinct. He is never content simply to absorb from others but thinks for himself around every subject with which he comes into contact. (Personal communication 2).

He started a post-graduate course at John Hopkins University in 1895 (Henderson, 1897, pp. 85-86) and was awarded a $\$ 500$ Fellowship in 1896 as part of the university's policy of bringing the institution into closer touch with the community. The purpose of the awards was to encourage advanced study among graduates of the Johns Hopkins or of other colleges to pursue graduate studies at the university (Reporter, 1896b, p. 10). His research advisers for his doctorate were Professors Remsen (Palmer, 2018a) and Morse; the title for his research thesis was $A$ further investigation of the symmetrical chloride of paranitro-orthosulphobenzoic acid (JHU, 1897, p.75) he received his Ph.D. degree in 1897. It is interesting to note that although his thesis was on an area of organic chemistry, his subsequent career and research interests related to inorganic and physical chemistry. These areas included the action of aluminium chloride on unsaturated compounds, the reaction of sulfuric acid with metal sulfides, the hydrolysis of ethyl acetate, and the thermal decomposition of metal dithionates (Mainz and Girolami, 1998).

After completing his doctorate, Dr William E. Henderson succeeded Dr Irving W. Fay as head of the Chemistry Department at Ohio University in 1897 staying for just two years; he was replaced by Dr J. P. Sylvester (Athena, 1923, p. 59). The following passage may indicate how he might have known of a vacancy at Ohio State University.

Dr Henderson, while at Ohio University [Athens] used to attend regularly the meetings of the Columbus section of the American Chemical Society-and so made the acquaintance of chemists here. (Personal communication 3)

He moved to teach chemistry temporarily at Ohio State University as Assistant Professor of Chemistry whilst Professor Foulk had leave of absence for two years graduate study in Germany under Ostwald at Leipzig (Caley, 1978, p. 131). Henderson proved himself to be a useful addition to the Department adding strength in the teaching of inorganic and physical chemistry and the history of chemistry. By the time Professor Foulk returned, the number of students had increased greatly, so Henderson was appointed as Associate Professor of Chemistry in 1901. Table 2 in Appendix 2 provides a brief summary of the lives of McPherson and Henderson. 


\section{CHEMISTRY AT OSU (1903-1940)}

The second chemistry building burnt down on the evening of $19^{\text {th }}$ February 1904 ; the fire that also destroyed large quantities of recently purchased apparatus and chemicals (Caley, 1978, p. 131). This was replaced by a third chemistry building which was completed in 1906 . This building lasted until 1926 when it was repurposed. The department was staffed with the members who guided its expansion over the next forty years. These were McPherson, Henderson, Foulk and Evans; Norton continued some teaching for a few years and James R. Withrow, Clarence C. Vogt and Cecil E. Boord were added to the staff prior to the First World War. In the early years, there were comparatively few staff for many students. All staff taught throughout the general courses. Initially, opportunities for research and specialisation were limited. In the earlier years there were few research publications; there were only seventy-two departmental publications between 1895 and 1923 with the majority of these being in the latter part of this period. The factors causing this were the limited number of staff, the heavy teaching loads, the concentration on course revision and writing textbooks and laboratory manuals for these courses and the small number of postgraduate students (Caley, 1978, p. 135). Both McPherson and Henderson continued on successful careers paths within OSU and obtained increasing recognition in the broader field of American science.

\section{WILLIAM MCPHERSON: LATER YEARS}

In January 1903, Professor McPherson proposed a new course in Chemical Pedagogy designed for students who were expecting to teach high school chemistry and he taught this course initially (Batchellor, 1973, p. 80). In 1905, the newly appointed William L. Evans was placed in charge of the elementary work. This venture into the teaching of chemistry persuaded McPherson and Henderson to write their famous series of texts and manuals which will be discussed later. William McPherson added to the influence and reputation of the Ohio State University Department of Chemistry by housing Chemical Abstracts within the Department. The Chemical Abstracts Service was founded in January 1907 by William Noyes and was moved to OSU in 1909 (URL: CAS history).

Many years earlier, when Professor Norton had been in charge of chemistry, he had been controlled financially by having to ask the university trustees for small purchases such as twenty -five dollars to purchase essential chemicals or seventy-seven dollars with which to purchase Watt's Dictionary of Chemistry. McPherson proposed the establishment of a Graduate School to update the thinking of the administration. This would bring the trustees to the realisation that they were running a university and not an elementary school (Brooks, 1930, p. 100). In 1911, the Graduate School was established. largely through McPherson's efforts and McPherson became its first Dean; he retained that position until he retired in 1937. In 1916, when the Graduate school was only five years old, he enthused that 'it has had a remarkable influence in increasing the output of productive scholarship in the University.' (McPherson, 1916, p. 40).

McPherson's chemical research was limited due to his heavy administrative and teaching duties. His own major research interests were on the formation of plant carbohydrates, vitalism and the reactions between substituted hydrazines and quinones (Eblin, 1976b, p. 329). He wrote several joint papers with postgraduate students and these were concentrated between 1907 and 
1911. After 1915, his publications generally related to teaching chemistry and the communication of chemical issues (Evans, 1952, p. 861-862).

In the first World War, he served in an advisory civilian capacity but was eventually commissioned (Patterson, 1917, p. 7) in the Chemical Warfare Service obtaining the rank of Lieutenant-Colonel by the end of the war. His main task was to "speed up the production of chlorine, bromine, and mustard gasses in the commercial plants" (Minderman, 1934, p. 1). He wrote an interesting account of American efforts to catch up on research into poison gasses before the end of the first World War (McPherson, 1920, pp. 200-209). He was evidently successful in his brief army career:

During those trying years of the World War, when nearly everybody's nerves were on edge, Professor McPherson was in khaki, and the military authorities soon discovered that when things got into such a jam that the only output was profanity, there was one man who could be depended upon to smooth things out again-McPherson.

(Brooks, 1930, p. 100).

His wife, Lucretia, was one of the prominent Ohio women involved in the suffrage movement (URL: Lucretia Heston McPherson); she died, aged 49, on 23 August 1923. In 1924, he was appointed as acting President of OSU, whilst the President, Dr W. O. Thompson, who had been granted leave of absence, was away (Reporter,1923a, p.1). In 1925, he married Henderson's sister Mary Browning Henderson. Due to increasing his duties as Dean of the Graduate School, McPherson resigned as the chairman of the Chemistry Department in 1928. McPherson was a strong supporter of the American Chemical Society in which he held a number of influential positions. From 1909 to 1911, he served as one of the two vice presidents, from 1923 to 1926, he served as a Councillor and in 1930, he was elected President of the American Chemical Society (Caley, 1970, p.11). He retired in 1937, taking Emeritus roles in Chemistry and with the Graduate School. However, in 1938 he was called back to serve as Acting President of OSU for about a year and a half when President Rightmire retired. On his final retirement he was given the title President Emeritus by the Board of Trustees. He was presented with an honorary degree, LLD, from OSU in June 1940 (URL: Honorary degree). William McPherson died on $2^{\text {nd }}$ October 1951 after a long illness at the age of 87.

\section{WILLIAM EDWARDS HENDERSON: LATER YEARS}

Henderson was promoted to Professor of Inorganic and Physical Chemistry in 1908 (Eblin, 1976a, p. 210: Anon, 1911, p. 873). being modified to Professor of Inorganic Chemistry in 1912. In 1913, he was elected as a member of the Board of Trustees at Wooster University (Reporter 1913, p.1). He was Secretary of the Council of the American Association for the Advancement of Science (AAAS) in 1915 and in 1916 became General Secretary of the AAAS. During the later stages of World War 1, Henderson and other senior staff spent much of their time on war duties (Batchellor, 1973, p. 116), which meant that first year classes were often taught by inexperienced staff.

In 1917, he was elected Secretary of the Division of Inorganic and Physical Chemistry of the American Chemical Society and in 1918 became the Chairman of the Division (Barbara, 1996, p. 12698). He was appointed as the Dean of the College of Arts, Philosophy and Science, OSU in 1921, a post that he retained until 1927 (Caley, 1970, p. 11). In 1925 he was awarded an honorary D.Sc. degree from the University of Wooster (Eblin, 1976a, p. 210). His mother, Jane, died on $6^{\text {th }}$ September 1926 . He had numerous administrative duties associated with this such 
as representing the University at the annual meeting of the Deans of Colleges of Liberal Arts (Reporter, 1926a, p. 1)

On $2^{\text {nd }}$ April 1922, he married Miss Frances Lucas of Providence, Rhode Island (Reporter 1922, p. 11). Lucas had been principal of the Lincoln School, Providence, a girls' school for day and boarding students. She was well known as a public speaker in Rhode Island, lecturing on social and political issues; she was also a committee member of the Rhode Island Equal Suffrage Association (RIESA) (Kabala, 2021). Frances Lucas Henderson died on $25^{\text {th }}$ December 1944 (Reporter 1944, p. 7). During their life together, they continued broad academic interests and liberal causes. Henderson was a committed member of the Congregational Church but unlike many other Congregationalists of the time was prepared to speak against proposed legislation to forbid the teaching of evolution in schools. He wrote:

Evolution is the most plausible theory of the presence of mankind. Everybody should take the theory study it and draw their own conclusions. Evolution has nothing to do with the story of Adam and Eve. Scientific men work with matters of fact and with evidence at hand. To bar the teaching of evolution in public schools is to bar further advances of science (Reporter 1925, p. 3).

Henderson's wide range of interests is shown by an article he wrote linking his knowledge of inorganic chemistry to archaeology. Archaeologists thought that the hardening of copper by quenching was a 'lost art'; Henderson pointed out that heating copper and plunging it in water softened copper and had always done so. However soft copper saws were used to cut granite by adding emery dust whilst sawing the rock. He clarified several other archaeological misconceptions in the same brief article (Henderson, 1925, pp. 12-13).

In 1926, the new President of OSU, President Rightmire, pointed to a lack of coherence and unity in the University policies and to a neglectful attitude toward the freshman student; consequently, freshman results were terrible even after disastrous attrition rates (Batchellor, 1973, p. 130-131). The solutions involved placing a greater emphasis on general education, creating some further restrictions on options available to students, having more senior staff teaching freshman courses, giving greater personal attention to the students and forming a series of permanent committees to keep the problems under review (Batchellor, 1973, pp. 132144). The result of these decisions was that Henderson returned to the Department on a fulltime basis (Reporter, 1926b), teaching inorganic chemistry, the history of chemistry, chemistry bibliography and the general education course in science (Batchellor, 1973, p. 201).

Professor Henderson retired in 1941; he was presented with an honorary doctorate (LLD) from Ohio State University in 1948 (URL: Honorary degree) He died on Sunday 30 ${ }^{\text {th }}$ September 1962 (Reporter, 1962) at Columbus, Ohio and was buried at Wooster on $3^{\text {rd }}$ October. The media did remember his ninetieth birthday with a revealing article about his reflections on progress and continuity of science "science is never finished by anybody". He regretted that chemistry "hasn't got yet to where it understands much about the human body". (McGary, 1960). Only a few scientific or newspaper obituaries can be found, perhaps because most of his friends had pre-deceased him.

\section{THE MCPHERSON /HENDERSON TEXTBOOKS AND MANUALS}

The McPherson/Henderson textbooks and manuals first appeared in 1905 and continued in publication until the 1960s. They were probably only outlasted by the series of textbooks and manuals written by Raymond B. Brownlee, Robert W. Fuller, William J. Hancock, Michael D. 
Sohon, and Jesse E. Whitsit (Palmer, 2017). The most common earlier textbooks and manuals were written by Ira Remsen (Palmer, 2018a) and Rufus P. Williams (Palmer, 2018b) in the early 1890s and Alexander Smith (Cotter, 2008. pp. 221-256) in the early 1900s.

The first textbook that McPherson and Henderson wrote together was entitled An introduction to the study of inorganic chemistry (McPherson \& Henderson, 1904). It was published internally and presumably was for the students on Henderson's course in inorganic chemistry. The first book of the major series of books that McPherson and Henderson wrote jointly was entitled An elementary study of chemistry published by Ginn \& Co in 1905. It was accompanied a year later by a laboratory manual entitled Exercises in chemistry: systematically arranged to accompany McPherson and Henderson's Elementary study of chemistry (See Appendix 1A).

Before publishing the McPherson-Henderson textbook and manual, McPherson wrote an article dealing 'with the text-book in elementary chemistry' expressing what he believed were 'some of the requisites of such a text-book as is suitable for use in our secondary school' (McPherson, 1904, p.1). He considered that 'the experiments intended for the pupil should be such as can be performed by the pupil. The apparatus described should be as simple as possible and should be such as is available in the average school.' (McPherson, 1904, p. 4). He gave examples of problems such as the cost of chemicals or apparatus '... the pupil is instructed to burn some calcium and compare the oxide formed with ordinary lime. ...calcium is quoted at $\$ 12.50$ per gram' (McPherson, 1904, p. 5). He also condemned the experiment of burning magnesium to illustrate chemical change on the grounds that it was not a common material known to students preferring to use the burning of a wooden splint as an example. It may be salient to note that in his textbook (McPherson \& Henderson, 1905) he followed his own advice using wooden splints as an exemplar of chemical action. McPherson (1904, p.10) shows his enthusiasm for practical chemistry by stating that if he were forced to choose either teaching chemistry without theory or chemistry without practical, he would tend to omit chemical theory. In terms of writers of chemical textbooks, he thought that 'it is only the individual who is intimately acquainted with the limitations as well as possibilities of the pupil in the secondary school who will succeed in writing a workable text (McPherson, 1904, p. 6). He briefly entered the controversial field of the heuristic method put forward by Professor Armstrong (Palmer, 2020) stating that 'Without entering into a discussion of the advantages of this method [heurism], it is certain to fail in the vast majority of our schools' (McPherson, 1904, p. 13)

At the time that they wrote that book together they were both young men with no experience of writing books. However, both men had racked up considerable teaching experience. Henderson's PhD supervisor had been Ira Remsen (Palmer, 2018a) who had written one of the foremost chemistry laboratory manuals of its era and as a postgraduate student, Henderson would have looked after many undergraduate practical chemistry classes for Remsen. The usual reason given for McPherson and Henderson writing a new book for the OSU Chemistry Department was that existing books were found to be 'too academic for our needs' (Personal communication 3) and that the new book placed more reliance on the modern concepts of physical chemistry (Eblin, 1976a, p. 210). McPherson and Henderson evidently wrote the textbook whilst 'on a summer holiday on one of the Lake Erie islands' (Personal communication 3). Reflecting on the past at the age of 90 Henderson said that he and McPherson wrote the book because 'they hounded us to do so' (McGary, 1960). A Columbus 
printer printed a two-year supply of the new paper-backed book and then prepared an improved hard-backed copy prior to its publication by Ginn \& Co. (Personal communication 3). One of the earliest reviews of An elementary study of chemistry also confirms the fact that the book was tried out by OSU students prior to publication. The reviewer, Professor Edward A. Renouf of Johns Hopkins University, stated that 'This manual has been in use - in privately printed form - for 3 years at the Ohio State University. After such revision as experience suggested, it is now offered to the public' and he continued stating that 'The book can be cordially recommended as an excellent manual for high schools and for elementary college work.' (Renouf, 1907)

In America, the common system at that time was for students to use two books for learning chemistry. The first was the textbook. The second was the chemistry laboratory manual which belonged to each student and had space for the student to answer the questions asked about the experiments they were performing. Usually, the instructions and questions were on the lefthand page, whilst the students wrote their answers on the blank right-hand page. This standard format made the task of the teacher or instructor much easier and could give the students a greater sense of ownership of their work.

A total of thirty-four reviews for thirteen McPherson-Henderson textbooks and manuals were found (see Appendix 1A). The titles of an additional fourteen textbooks and manuals whose reviews were not found, are listed in Appendix 1B. Additionally, several of the textbooks went through three or four editions. The publication of any new edition required considerable editorial work. As the load of administration increased for McPherson, he was able to do less of the editorial work involved with the textbooks and Henderson after about 1908 took the major responsibility for textbook revision. All the books that were reviewed, received glowingly positive reviews with only minor suggestions for improvement. Extracts from these reviews can be seen in Appendix 1C. Eblin (1976a, p. 210) stated that:

The McPherson-Henderson textbooks are amongst the most widely used chemistry textbooks ever published. They were adopted by hundreds of colleges and the number of students who used one or more of them is estimated to approach two million (Eblin 1976a, p. 210).

When the books were first written many students at OSU had not had the opportunity to learn chemistry at secondary school, so the level of teaching freshman students was similar to that needed by schools. The books thus sold well in secondary schools, colleges and to universities for first year students. Over the years, most schools began to teach chemistry which improved the standards of first year students at universities, so new books were needed. Also, McPherson and Henderson wished to emphasise the uses of chemistry and its value in the world of work, so they wrote new books with laboratory manuals to emphasize these ideas together with problem books and teachers' key books to assist new teachers. They built up a sense of trust in the product, so even as age took its toll for McPherson and Henderson, many members of the OSU chemistry Department contributed their skills. The harshest criticism of the later books probably comes from Henderson himself:

Revised many times by other collaborators the text does not please as much as it once did. 'The boys at the university have increased it too much. It's too big, not quite as simply written as it once was' he complained (McGary, 1960). 


\section{SOME FINANCIAL ASPECTS OF TEXTBOOK WRITING: TO WHOSE BENEFIT?}

Under the American system of each student needing a textbook and a practical manual, each student purchased two books. The manual was linked to a specific text usually by the same author. The school, college, university or local education authority decided which book and manual the student would purchase. Two examples of authorities making decisions to use McPherson-Henderson textbooks follow. In the first case, the authorities seem to have negotiated a good price as they would have purchased a large number of books. The selection of textbooks for Louisville's schools were completed last choosing the following texts and manuals.

An Elementary Study of Chemistry Second Revised Edition (Ginn \& Co.). \$1.20. Laboratory Exercises. Arranged to Accompany "An Elementary Study of Chemistry" (Ginn \& Co.). 33 cents. (Reporter, 1919, p. 5).

Similarly, parents from Alexandria, Indiana were told in the local newspaper what textbooks their children would require; for chemistry they would need to purchase Chemistry and Its Uses, McPherson \$1.44 and Laboratory Practice in Chemistry [no price given] (Reporter, 1923 b, p. 1). It is interesting to observe that the McPherson-Henderson textbooks had become popular right across America.

At the time when McPherson and Henderson were ready to publish, several publishers were interested. They chose Ginn \& Company of Boston whose founder was Edwin Ginn. Ginn had Congregationalist connections and was influential in the Peace movement; he became the leading American textbook publisher. McPherson and Henderson thus chose someone who not only had similar views to themselves but who also was a shrewd businessman. A major part of the success of their textbooks and manuals was due to their publisher.

Henderson's ambition had been to become a doctor. However, in a discussion about his life with a journalist, Henderson, who was troubled by poor hearing and severe lameness, confessed that he took up chemistry not expecting to become a teacher, but he said because "I thought if I took a chemistry course at least I could run a drug store." (McGary, 1960). His background was certainly of some financial stress so his position gave him opportunities that he could not have dreamed of as a young man.

In 1916, McPherson's annual salary as Professor of Chemistry and Dean of the Graduate School was \$4000.00 whilst Henderson's annual salary as Professor of Inorganic and Physical Chemistry was $\$ 3000.00$ (URL: Forty-sixth annual report) which were good salaries at that time. They would also have had a considerable income from their books increasing with their improving book sales.

Dr Henderson has always been interested in General Science (botany especially in addition to chemistry) and in its philosophy. His interest in botany was shown through his bequest to Wooster University of $\$ 400,000$ to establish the Horace N. Mateer Professorship of Biology (Reporter, 1962, p. 24). This is a huge sum of money for Henderson to have saved during his lifetime and indicates that textbook writing was a profitable interest.

\section{CHARACTER}

The final thoughts summarising William McPherson's life were expressed by his friend and colleague Professor William Lloyd Evans. 
After a prolonged illness, this very notable and distinguished career came to a close on the morning of October the second 1951. William McPherson was a man of many gifts, not least of them being a talent for friendship and a sincere interest in those whom he called friends. His ways of showing this could be verified by many who caught their inspiration from his lips and from his life. When to his personal charm is added his ability as teacher and chemist and administrator, William McPherson will remain in the memory and hearts of those who knew him as a man of great stature (Evans, 1952, p.861).

The Ohio State University Board of Trustees in a memorandum of $12^{\text {th }}$ October 1962 wrote the following tribute to Professor Henderson:

Doctor Henderson lived a rich and full life. He contributed much to the scholarly and spiritual life of our university community. He helped build the Ohio State University in it early critical and formative period. He will be long remembered by his students and colleagues for his courageous, objective, scholarly, statesmanlike approach to the great variety of problems that must be studied and resolved in an academic community (Personal communication 3).

\section{CONCLUSION}

The collaboration between William McPherson and William Edwards Henderson was extremely valuable in producing a series of top rate chemistry textbooks and manuals lasting nearly half a century which benefitted them, their students and Ohio State University's reputation.

\section{REFERENCES}

Anon (1911). University and Educational News Science, New Series, Vol. 34, No. 886 (Dec. 22, 1911), pp. 873.

Athena 1923, Vol 19, p. 59 by Ohio University (Accessed 14/02/2021) at URL: https://archive.org/details/athena19ohio

Barbara, P. F. (1996). A brief history of physical chemistry in the American Chemical Society, Journal of Physical Chemistry, 100, 12694-12700.

Batchellor, R. W. (1973). The development of the general chemistry program at the Ohio State University. Presented in partial fulfilment of the requirements for the Degree Doctor of Philosophy in the Graduate School of The Ohio State University. Ph.D. (Education, higher). 74-3116 Xerox University Microfilms. (Accessed 14/02/2021) At URL: https://etd.ohiolink.edu/apexprod/rws_etd/send_file/send?accession=osu1487352168097336 \&disposition=inline

Brooks, B. T. (1930). American contemporaries: William McPherson, Industrial and engineering chemistry 22(1)100.

Caley, E. R. (1970). History of the Department of Chemistry. Columbus, Ohio: The Ohio State University Department of Chemistry. (Accessed 14/02/2021) At URL: https://kb.osu.edu/bitstream/handle/1811/22532/V078N3_129.pdf?sequence=1 
Caley, E. R. (1978). Early history of the department of chemistry of the Ohio State University, Ohio Journal of Science, 78(3)129-135.

CAS history (Accessed 21/02/2021) at URL: https://www.cas.org/about/cas-history

Cotter, D. (2008) A disciplinary immigrant. Alexander Smith at the University of Chicago, 1894-1911, Annals of Science, 65:2, 221-256, DOI: 10.1080/00033790701576206

Eblin, L. P. (1976a). William Edwards Henderson (1870 -1962), American chemists and chemical engineers. (edited Wyndham D. Miles), Washington, D.C.: American Chemical Society, pp. 209-210).

Eblin, L. P. (1976b). William McPherson (1864-1951), American chemists and chemical engineers. (edited Wyndham D. Miles), Washington, D.C.: American Chemical Society, pp. 328-329.

Evans, W. L. (1952). William McPherson July 2, 1864 - October 2, 1951, Journal of the American Chemical Society, 74(4)859-862 (21 ${ }^{\text {st }}$ February).

Forty-sixth annual report of the Board of Trustees of the Ohio State University to the Governor of Ohio for the year ending June $30^{\text {th }} 1916$, Press of Ohio State Reformatory 1917 at URL: https://core.ac.uk/download/pdf/159563943.pdf

Hart, H. (2021). Sidney Augustus Norton (1835-1918) (Accessed 14/02/2021) at URL: https://www.chemistry.msu.edu/faculty-research/portraits/sidney-augustus-norton/

Henderson, W. E. (1897). Doctoral thesis, Johns Hopkins University. A further investigation of the symmetrical chloride of paranitro-orthosulphobenzoic acid (Accessed 19/02/2021) at URL: https://archive.org/details/furtherinvestiga00hend/page/n189/mode/2up

Henderson, W. E. (1925). The Lost Arts, Industrial and Engineering Chemistry, 20 ${ }^{\text {th }}$ September, pp. 12-13.

Honorary degree, Ohio State University, June 1948 (Accessed 19/02/2021) at URL: https://universityawards.osu.edu/archives/honorary-degree-recipients-archive

Index 1890-1891 (published May 19th, 1890), junior history, p. 54 (Accessed 27/02/2021) at URL: https://openworks.wooster.edu/cgi/viewcontent.cgi?article $=1025 \&$ context $=$ index 1870 1920.

JHU (1897). Johns Hopkins University circulars published with the approbation of the board of trustees Vol. XVI. - no.131. Baltimore, July 1897.p. 75, (Accessed 14/02/2021) at URL: https://jscholarship.library.jhu.edu/bitstream/handle/1774.2/32964/I131.PDF?sequence=1

Kabala, J. S. (2021). Biographical Sketch of Frances Lucas in Part III: Mainstream Suffragists-National American Woman Suffrage Association (Accessed 14/02/2021) at URL: https://documents.alexanderstreet.com/d/1010113854

Lucretia Heston McPherson at URL (Accessed 7/03/2021): https://www.ohiomemory.org/digital/collection/p267401coll32/id/27829

Mainz, V. V. and Girolami, G. S. (1998). Genealogy database entry (Accessed 14/02/2021) at URL: http://web-genealogy.scs.illinois.edu/Info/hendersonwe.pdf 
McGary, M. (1960). Ex-OSU teacher great nears 90. Columbus Dispatch, Columbus, Ohio 29 January.

McPherson, W. (1904). The text-book in elementary chemistry. School Science and Mathematics, 4: 1-15. https://doi.org/10.1111/j.1949-8594.1904.tb00782.x

McPherson, W. (1916). Forty-sixth Annual Report of the Board of Trustees of the Ohio State University to the Governor of Ohio for the year ending June 30, 1916, p. 40 (Accessed 26/03/2021) at URL: https://core.ac.uk/download/pdf/159563943.pdf.

McPherson, W. (1920). Chemical Warfare Service and chemical teaching, School Science and Mathematics, 20, pp. 200-209.

McPherson, W. (1931). The history of the department of chemistry of the Ohio State University, Journal of Chemical Education, 8(4)640-651.

McPherson, W., \& Henderson, W. E. (1904). An introduction to the study of inorganic chemistry. Columbus, Ohio: Chemical laboratory of the Ohio State University, (Accessed 24/03/2021) at URL:

https://babel.hathitrust.org/cgi/pt?id=loc.ark:/13960/t7qn78918\&view=image \&seq=5

McPherson, W., \& Henderson, W. E. (1905). An elementary study of chemistry. Boston: Ginn and Co.

McPherson, W. \& Weber, H. A. (1895a). On the determination of cane-sugar in the presence of commercial glucose," Journal of Chemical Education, 17,312-320.

McPherson, W. \& Weber, H. A. (1895b). On the action of acetic and hydrochloric acids on sucrose, Journal of Chemical Education, 17, 320-327.

Mendenhall, T. C. and Cope, A. (1920). History of the Ohio State University - Volume 1 (18701910). Columbus, Ohio: The Ohio State University Press.

Minderman E. (1934). Still hitting the ball, The Columbus Citizen, Columbus, Ohio, Thursday, $15^{\text {th }} \quad$ November, p.1. At URL: https://library.osu.edu/sites/default/files/collection_files/biographical_files/McPherson_Willi am.pdf.

Palmer, W. P. (2017). The story of a long-lasting chemistry textbook and its authors, History Division, Grand Hyatt, Washington, DC, 254th American Chemical Society National Meeting Washington (August 20-24) at URL: Palmer: Story of a long-lasting chemistry textbook... Google Scholar

Palmer, W. P. (2018a). Ira Remsen: stories for chemical education: Chemistry in Australia (September/October), pp. 26-29. (Accessed 19/03/2021): See URL:

http://chemaust.raci.org.au/article/septemberoctober-2018/ira-remsen-stories-chemicaleducation.html.

Palmer, W. P. (2018b). Rufus Phillips Williams (1851-1911): an exceptional Nineteenth Century American teacher of chemistry, American Chemical Society Annual Meeting 2018, History of Chemistry Division, Boston, MA, 19-23 August at URL: Palmer: Rufus Phillips Williams (1851-1911): An exception... - Google Scholar 
Palmer, W. P. (2020). Henry Edward Armstrong (1848-1937) and his Australian Adventures, at the Science and Mathematics International Conference (SMIC) 2020, 8-9 August 2020, Faculty of Mathematics and Natural Science, Universitas Negeri Jakarta, Indonesia: at URL: https://confbrite.org/2020/smic/kfz/abstract/XbLsxwmg9.

Patterson, A. M. (1917). Chemists are optimistic on outcome of war, Xenia Daily Gazette Xenia, Ohio, $26^{\text {th }}$ September, Wednesday, Page 7.

Personal communication 1, James Stimpert, Senior Reference Archivist, Special Collections, Sheridan Libraries, Johns Hopkins University (RG11-010) on Tuesday 16/02/2021.

Personal communication 2, James Stimpert, Senior Reference Archivist, Special Collections, Sheridan Libraries, Johns Hopkins University (Student file) on Tuesday 23/02/2021.

Personal communication 3, William Edwards Henderson [biographical articles] with Halle Mares, (18/03/2021) University Libraries Archives, Ohio State University, Columbus, Ohio.

Renouf, (1907) Review of An Elementary Study of Chemistry. in American chemical journal, Vol. 37 (Jan-June)

Reporter (1891). Our Faculty, College Life, Emporia Kansas, Saturday $10^{\text {th }}$ October, Vol 4, No 1. p.1.

Reporter (1893). Interesting features, College Life, Emporia Kansas, Wednesday $7^{\text {th }}$ June.

Reporter (1894). What they say, College Life, Emporia Kansas, Monday $24^{\text {th }}$ September, p. 7.

Reporter (1896a). Notes, Emporia Daily Republican Emporia, Kansas $10^{\text {th }}$ June, Wednesday, Page 4.

Reporter (1896b). A popular move to put the Johns Hopkins in closer touch with the people, The Baltimore Sun Baltimore, Maryland, $2^{\text {nd }}$ June, Tuesday, Page 10.

Reporter (1913). State man is Wooster trustee The Ohio State Lantern, Columbus, Ohio, 29th October, Page 1

Reporter (1919). Schoolbooks are adopted The Courier-Journal Louisville, Kentucky $30^{\text {th }}$ April, Wednesday, page 5.

Reporter (1922) Miss Frances Lucas wed. New York Herald, New York $3^{\text {rd }}$ April, Monday, Page 11.

Reporter (1923a). William McPherson named Ohio State head, Hamilton Evening Journal Hamilton, Ohio $22^{\text {nd }}$ December Saturday, Page 1.

Reporter (1923b). High School Text Books The Alexandria Times-Tribune Alexandria, Indiana, $7^{\text {th }}$ September, Friday, page 1

Reporter (1925). Savants oppose Bryan, The Miami Herald Miami, Florida, $29^{\text {th }}$ May, Friday, Page 3

Reporter (1926a). Dean W. E. Henderson Attends Deans' Meeting, The Ohio State Lantern, Columbus, Ohio, $11^{\text {th }}$ May, page 1

Reporter (1926b). Dean W. E. Henderson resigns as Head of the Arts College, The Lantern, $26^{\text {th }}$ April, pages 1 and 4. 
Reporter (1944). Educator's Wife Dies, The Journal Herald Dayton, Ohio, $25^{\text {th }}$ December, Tuesday, page 7.

Reporter (1951). Ohio State Dean Emeritus Dies at 87, The Star Press Muncie, Indiana, 04 October, Thursday, page 5.

Reporter (1962). Wooster given $\$ 400,000$ bequest, $5^{\text {th }}$ November, Monday, page 24.

Twelve Days of Buckeyes: “3” (Accessed 7/03/2021) at URL: https://library.osu.edu/site/archives/2012/12/19/twelve-days-of-buckeyes-3-apparently-is-acharm-for-the-chemistry-department/ 


\section{APPENDIX 1 A}

TABLE 1 SHOWING NUMBER OF BOOK REVIEWS.

\begin{tabular}{|c|c|c|c|}
\hline Textbook & Authors & $\begin{array}{l}\text { Publication } \\
\text { Date }\end{array}$ & $\begin{array}{l}\text { Number of } \\
\text { Reviews }\end{array}$ \\
\hline i.An elementary study of chemistry. & W M \& WEH & 1905 & 5 \\
\hline $\begin{array}{l}\text { ii.Exercises in chemistry: systematically arranged to } \\
\text { accompany McPherson and Henderson's Elementary } \\
\text { study of chemistry. }\end{array}$ & W M \& WEH & 1906 & 1 \\
\hline iii.A course in general chemistry & W M \& WEH & 1913 & 2 \\
\hline $\begin{array}{l}\text { iv.Laboratory manual: arranged to accompany "A } \\
\text { course in general chemistry" }\end{array}$ & W M \& WEH & $\begin{array}{l}1915 \\
+ \text { WLE } 1928\end{array}$ & 1 \\
\hline v.First course in chemistry & W M \& WEH & 1915 & 1 \\
\hline $\begin{array}{l}\text { vi. Laboratory manual: arranged to accompany "A } \\
\text { first course chemistry" }\end{array}$ & W M \& WEH & 1915 & 2 \\
\hline $\begin{array}{l}\text { vii.Chemistry and its uses: a textbook for secondary } \\
\text { schools }\end{array}$ & W M \& WEH & 1922 & 6 \\
\hline $\begin{array}{l}\text { viii.Laboratory practice in chemistry: exercises to } \\
\text { accompany "Chemistry and its uses" }\end{array}$ & W M \& WEH & 1922 & 0 \\
\hline ix.Chemistry for today. & $\begin{array}{l}\text { W M, WEH \& } \\
\text { GWF }\end{array}$ & 1930 & 3 \\
\hline x. A laboratory work book & $\begin{array}{l}\text { W M, WEH \& } \\
\text { GWF }\end{array}$ & 1930 & 2 \\
\hline xi.Chemistry at work & $\begin{array}{l}\text { W M, WEH, } \\
\text { WCF \& GWF }\end{array}$ & 1938 & 5 \\
\hline $\begin{array}{l}\text { xii. Laboratory units in chemistry: manual and study } \\
\text { guide for chemistry at work. }\end{array}$ & $\begin{array}{l}\text { W M, WEH, } \\
\text { \& GWF }\end{array}$ & 1938 & 2 \\
\hline xiii.Chemistry, a textbook for colleges. & $\begin{array}{l}\text { W M, WEH, } \\
\text { WLE, WCF \& } \\
\text { EM }\end{array}$ & 1940 & 3 \\
\hline xiv. Introduction to college chemistry & $\begin{array}{l}\text { W M, WEH, } \\
\text { WCF \& LLQ }\end{array}$ & 1942 & 1 \\
\hline TOTAL NUMBER OF REVIEWS & & & 34 \\
\hline
\end{tabular}

Authors are William McPherson (W M); William Edwards Henderson (W E H); William Lloyd Evans (W L E); W Conard. Fernelius (W C F); Edward Mack (E M); George Winegar Fowler (G W F); Laurence Larkin Quill (L.L.Q) and can be recognised by their initials.

Appendix 1B lists the reviews of the McPherson/Henderson textbooks and manuals that could be found, providing detailed references for the reviews and a short typical quotation from each.

\section{APPENDIX 1 B TITLES OF BOOKS NOT REVIEWED.}

McPherson, W., \& Henderson, W. E. (1904). An introduction to the study of inorganic chemistry. Columbus, Ohio: Chemical laboratory of the Ohio State University,

McPherson, W., Henderson, W. E., \& McPherson, W. (1915). Teachers' manual to accompany First course in chemistry. Boston: Ginn \& Co.

McPherson, W., \& Henderson, W. E. (1915). Problems reprinted from "A course in general chemistry". Boston: Ginn. 
McPherson, W., \& Henderson, W. E. (1919). Teacher's manual for an elementary study of chemistry. Boston: Ginn.

McPherson, W., \& Henderson, W. E. (1922). Laboratory practice in chemistry: exercises to accompany Chemistry and its uses. Boston: Ginn.

McPherson, W., \& Henderson, W. E., "A Course in General and Chemistry," Chinese Edition (Huí C. Tsao and W. H. Adolph), 648 pp. China Medical Missionary Association, Shanghai, 1922.

McPherson, W., \& Henderson, W. E. (1926). Laboratory practice in chemistry edition spaced for answers. Boston: Ginn.

McPherson, W., Henderson, W. E. \& Fowler, G. W. (1930). Teacher's key and manual for Chemistry for today. Boston: Ginn and Co.

Henderson, W. E., Kane, E. P., McPherson, W., \& Fowler, G. W. (1932). Teachers' key for A laboratory workbook by William McPherson, William Edwards Henderson, and George Winegar Fowler: And for Mastery tests in chemistry by George Winegar Fowler and Emmett P. Kane. Boston: Ginn.

Mai, F. S., Han, D. S., Fu, S., Hu, R., McPherson, W., \& Henderson, W. E. (1932). Hua xue gai lun. Shang hai: Shang wu

McPherson, W. (1933). Elementary treatise on qualitative analysis. Columbus, Ohio: The Varsity Supply Co. (Printed on one side of leaf only.)

Henderson, W. E., \& Fernelius, W. C. (1935). A course in inorganic preparations. New York: McGraw-Hill.

Wallace, W. J. L., Moore, P. J., \& McPherson, W. (1943). Study questions and problems in general chemistry. Institute, W. Va. (Reproduced from typewritten copy. Written to accompany "Chemistry, a textbook for colleges, by William McPherson, William Edwards Henderson, W. Conrad Fernelius ... and Edward Mack, jr."

McPherson, W., Henderson, W. E., \& McPherson, W. (2010). Introduction to chemistry. Oakville, ON: Apple Academics. (Originally published under title: An elementary study of chemistry.) 


\section{APPENDIX 1C}

i. Review. An Elementary Study of Chemistry. American chemical journal, Vol. 37 (Jan-June 1907). QUOTE: "At first sight the book would seem not to differ essentially from several other manuals, but a close examination shows that it is written with marked ability and great care."

Review: Elementary study of chemistry. The Journal of Education, Vol. 65, No. 7 (1617) (February 14, 1907), p. 188. QUOTE "An excellent treatise, and the result of years of experience in instruction in this line of study.' Review. An Elementary Study of Chemistry. School Science and Mathematics, 1918-05, Vol.18 (5), p. 482. QUOTE 'This revised edition of a text that has been well and favourably known to many teachers, brings it down to date ...'

Review. An Elementary Study of Chemistry. School Science and Mathematics, Volume25, Issue1, (January 1925), p.106. QUOTE 'In the rewriting of the text the general order of treatment has been left approximately as it was, but much new material has been added.'

Review. An Elementary Study of Chemistry. (Revised edition). Journal of Chemical Education. 1932, 9, 12, 2145, https://doi.org/10.1021/ed009p2145.1 QUOTE " "... the teacher of chemistry will appreciate the many corrections and additions the authors have made in bringing this excellent text up-to-date."

ii. Review. Exercises in chemistry: The Journal of Education, Vol. 65, No. 18 (1628) (May 2, 1907), p. 497. QUOTE "As an accompaniment to the fuller work of the authors, this work is invaluable."

iii. Review. A course in general chemistry. Journal of Chemical Education 1927, 4, 12, 1561. https://doi.org/10.1021/ed004p1561. QUOTE .... continued their policy of presenting a textbook that is both "scientific in spirit and thoroughly teachable".

Review. A Course in General Chemistry. Dominicana Journal Vol 12, No4, p.322. https://www.dominicanajournal.org/wp-content/files/old-journal-

archive/vol12/no4/dominicanav12n4friarsbookshelf.pdf. QUOTE: All the art of modern pedagogy has been marshalled against the ever-increasing complexity of modern chemistry in this third revision of a well-known textbook.

iv. Review Laboratory manual: arranged to accompany "A course in general chemistry" Journal of Chemical Education (1929) Vol. 6, No. 3, p. 591, https://pubs.acs.org/doi/pdf/10.1021/ed006p591.1. QUOTE "This excellent manual — one of the most attractive and carefully prepared of those now available in elementary general chemistry - is the result of many years of experience with large classes at the Ohio State University."

v. Review: A first course chemistry The Journal of Education, Vol. 81, No. 25 (2035) (JUNE 24, 1915), p. 709. QUOTE "This new book is quite up to its predecessor in ability, and contains the very latest discoveries in laboratory research, while its plan is arranged according to the best pedagogical methods".

vi. Review Laboratory manual: arranged to accompany "A first course chemistry" The Journal of Education Vol. 82, No. 12 (2048) (October 7, 1915), p. 329 QUOTE "All the experiments described can be performed with simple apparatus and inexpensive materials and will give the student a real insight into the principles of chemistry as well as into the applications of the science."

Review. Laboratory Manual, Arranged to Accompany " A Course in, Chemistry" by William McPherson and William Edwards Henderson. Volume. XLI, 1916) p. 144. QUOTE: "This book is a suitable companion to the authors' well-known text book and it gives an excellent series of experiments for laboratory work in connection with the study of elementary chemistry"

vii. Review Chemistry and its uses. The Journal of Education, Vol. 96, No. 7 (2393) (August 31, 1922), p. 192. QUOTE "All this information is in "Chemistry and its uses," and could have been in no textbook ten years ago. This is characteristic of the book."

Review Chemistry and its uses. The Journal of Education, Vol. 103, No. 22 (2582) (June 3, 1926), p. 616

QUOTE “ $\ldots$ is not only reliable and almost endless in the presentation of practical applications, but it is always so clear in its statements as to be easily appreciated and is withal literally fascinating."

Review Chemistry and its uses. The School Review, Vol. 31, No. 1 (January 1923), pp. 72-73. QUOTE "The book has many excellent features and doubtless will be found to be, not only an unusually teachable text, but also a splendid reference book for the beginner in chemistry." 
Review. Chemistry and its uses, School Science and Mathematics (1923-01), Vol.23 (1), p.92-102. QUOTE "This text attempts to make use of the appeal of the practical to induce interest on the part of the pupil."

Review. Chemistry and its uses, School Science and Mathematics, Volume26, Issue7, (October 1926), Pages 786794 QUOTE '. A successful effort has been made to stress the applications of chemistry while teaching the facts and laws and principles. ... All high school teachers of chemistry will be interested to see this text.'

Review: Chemistry and its uses. Science Progress in the Twentieth Century (1919-1933), 17(67), 488-488. QUOTE "For this reason we welcome this book and strongly recommend it to English schoolteachers of science.

viii. Laboratory practice in chemistry: exercises to accompany "Chemistry and its uses.

ix. Review Chemistry for today. The Journal of Education, Vol. 112, No. 2 (July 14, 1930), p. 44. QUOTE "It is one of the best demonstrations of true fact that the teachers are brought abreast the science and industries of the times by the texts they use."

Review Chemistry for today. Journal of Chemical Education 1930, 7, 10, 2526. https://doi.org/10.1021/ed007p2526.1. QUOTE "This book will be welcomed as an interesting and valuable addition to the lists of chemistry texts for preparatory schools. The first impressions from it are pleasing; ..."

Review. Chemistry for today. School Science and Mathematics, 1930-11, Vol.30 (8), p .970. QUOTE "Some excellent questions and problems are to be noted in these sections. The teaching of molecular weights is excellent. .... High School Chemistry Teachers will want to see this text."

x. Review: A laboratory workbook: The Science News-Letter, Vol. 18, No. 507 (Dec. 27, 1930), pp. 423-424. QUOTE "The authors of a widely used chemistry text, "Chemistry for Today," have here produced an excellent laboratory manual to accompany it."

Review: A laboratory workbook: School Science and Mathematics, Volume30, Issue9, (December 1930), p. 1096. QUOTE "Four preliminary experiments and thirty-eight exercises containing a total of ninety-six experiments."

xi. Review: Chemistry at Work. The Journal of Education, Vol. 122, No. 5 (May 1939), p. 176. QUOTE "A great deal of sane pedagogy has evidently been moulded into this new chemistry text for high schools."

Review: Chemistry at Work. The Science News-Letter, Vol. 34, No. 8 (Aug. 20, 1938), pp. 127-128. QUOTE "The college text book of McPherson and Henderson is so widely known ...."

Review: Chemistry at Work. The Science News-Letter, Vol. 53, No. 13 (Mar. 27, 1948), p. 207. QUOTE

"An abundantly illustrated high-school text that is both attractive and interesting."

Review: Chemistry at Work. Journal of Chemical Education 1939, 16, 7, 347. https://doi.org/10.1021/ed016p347.2. QUOTE "The organisation is effectively conservative and free from meaningless innovations and vagaries that characterized earlier unit treatments."

Review. Chemistry at Work. School Science and Mathematics, Volume 38, Issue 8, November 1938, pp 946-947. QUOTE. "Although the names of two of the authors are and have long been well and favourably known to chemistry teachers as writers of excellent texts this book is really a new book and not a revision of any previous text."

xii. Review. Laboratory units in chemistry: manual and study guide for chemistry at work: The Science NewsLetter, Vol. 34, No. 27 (Dec. 31, 1938), p. 428. QUOTE "A laboratory manual for a widely used college chemistry text."

Review. Laboratory units in chemistry: manual and study guide for chemistry at work. Journal of Chemical Education 1939, 16, 12, 598. https://doi.org/10.1021/ed016p598. QUOTE "Laboratory Units in Chemistry is a laboratory manual and study-guide for high school chemistry."

xiii. Review: Chemistry, a textbook for colleges. The Science News-Letter, Vol. 38, No. 18 (Nov. 2, 1940), p. 288. QUOTE "This latest addition to the McPherson and Henderson series of chemistry texts fully justifies their splendid reputation for accuracy and interest."

Review: Chemistry, a textbook for colleges Journal of Chemical Education,1941, 18, 5, 249. https://doi.org/10.1021/ed018p249.2. QUOTE "The authors have shown that such chemistry can be interesting and intellectually stimulating."

Review: Chemistry. Soil Science: July 1941 - Volume 52 - Issue 1, p 83. QUOTE A college textbook designed to give freshmen a glimpse into the intricacies of chemical phenomena without making the subject unduly difficult.' 
xiv. Review: Introduction to College Chemistry. Soil Science vol 60, No 3, pp.263-264. QUOTE "Teachers of freshman chemistry and persons in many other lines of endeavour will find the book of interest and value."

\section{APPENDIX 2}

\section{TABLE 2}

\section{LIVES OF WILLIAM MCPHERSON AND WILLIAM EDWARDS HENDERSON}

\begin{tabular}{|c|c|c|}
\hline EVENT & WILLIAM MCPHERSON & WILLIAM EDWARDS HENDERSON \\
\hline Date of birth & $2^{\text {nd }}$ July 1864 & $29^{\text {th }}$ January 1870 \\
\hline Date of first degree & B.S in 1887 & A.B in 1891 (Cum laude) \\
\hline $\begin{array}{l}\text { Years of teaching } \\
\text { experience before OSU }\end{array}$ & 6 years at Toledo High School, Ohio. & $\begin{array}{l}2 \text { years at Emporia: } 2 \text { years at Ohio } \\
\text { University }\end{array}$ \\
\hline Date of Ph.D. & $\begin{array}{l}1899 \text { from University of Chicago. } \\
\text { (Eblin, 1976, p. 328) }\end{array}$ & $\begin{array}{l}1897 \text { from Johns Hopkins University. } \\
\text { (Eblin, 1976, p. 209) }\end{array}$ \\
\hline Athletic ability & Brilliant athlete & Crippled leg, troubled by poor hearing \\
\hline Employment at OSU & $1892-1939$ & $1899-1940$ \\
\hline Marriage & $\begin{array}{l}\text { (i) } 21^{\text {st }} \text { June } 1892 \text { Lucretia Heston } \\
\text { died } 1923 \text {. (ii) Henderson's sister } \\
\text { Mary in } 1925\end{array}$ & Miss Frances Lucas on $2^{\text {nd }}$ April 1922. \\
\hline Religion & Congregationalist & Congregationalist \\
\hline Speciality in chemistry & Organic chemistry + Education & $\begin{array}{l}\text { Organic chemistry followed by } \\
\text { inorganic and physical }\end{array}$ \\
\hline Books & $\begin{array}{l}\text { Cooperated from } 1904 \text { producing } \\
\text { more than } 25 \text { joint books }\end{array}$ & $\begin{array}{l}\text { Cooperated from } 1904 \text { producing more } \\
\text { than } 25 \text { joint books }\end{array}$ \\
\hline Chemical research & Chemical research was limited & $\begin{array}{l}\text { More chemical research than } \\
\text { McPherson }\end{array}$ \\
\hline Professorships & Professor of Chemistry & Professor of Inorganic Chemistry \\
\hline Administrative positions & $\begin{array}{l}\text { Chairman of the Chemistry } \\
\text { Department: Dean of the Graduate } \\
\text { School. Acting President of OSU } \\
\text { (twice). }\end{array}$ & $\begin{array}{l}\text { Dean of the College of Arts, Philosophy } \\
\text { and Science }\end{array}$ \\
\hline Retirement & 1939 & 1940 \\
\hline Death & $2^{\text {nd }}$ October 1951 & $30^{\text {th }}$ September 1962 \\
\hline Character & Better administrator & More profound scholar. \\
\hline Probate & Unknown & $\$ 400,000$ to Wooster University \\
\hline
\end{tabular}

